\title{
Development of Manually Operated Piston Press Type briquetting Machine
}

\author{
Yomesh Sinha*, Pujyalal Sahu, Swarup Biswas, \\ Shivangi Manikpuri and Manish Lathiya
}

Department of Farm Machinery and Power Engineering, Chhattisgarh Agricultural Engineering College, Dhanora, Bhilai, India

*Corresponding author

\section{Keywords}

Biomass, tone, briquettes, screw, compaction

Article Info

Accepted:

20 November 2019

Available Online:

10 December 2019

\section{A B S T R A C T}

The demand for energy is increasing constantly with the increasing population of the world, and the major source of energy (oil and gas) is limited. Fossil fuels are the major source for energy. The excess use of these fuels will lead to serious environmental issues like global warming and air pollution. Since the fossil fuels are getting depleted day by day, it is the high time to convert biomass wastes such as sawdust, rice husk etc., to useful biomass briquettes which will be the substitute for some of the fossil fuels. This, calls for sustainable energy production and supply such as renewable energy technologies. In this study, a manually operated briquetting machine (a screw press) was designed and fabricated using locally available materials to ensure the sustainability of production and use of briquettes which is a renewable source of energy. The principal parts of the machine are the handle, screw, compaction chamber and frame.

\section{Introduction}

In recent years, the use of biomass as a source of energy became of great interest world-wide because of its environmental advantages. The use of biomass for energy production (biofuels) has been increasingly proposed as a substitute for fossil fuels. Fuel wood ranks first, at 252.1 million tonnes, followed by dung-cakes, at 106.9 million tonnes and agricultural residue, at 99.2 million tonnes of annual consumption. Similarly, the per capita consumption figures are also high for fuel wood at $250 \mathrm{~kg}, 50 \mathrm{~kg}$ for animal dung and $134 \mathrm{~kg}$ for crop residues. This is further corroborated by the energy consumption estimation given by NCAER (Gangadhar et al.,2015). Biomass can also offer an immediate solution for the reduction of the $\mathrm{CO}_{2}$ content in the atmosphere. It has three other main advantages: firstly its availability can be nearly unlimited, secondly it is locally produced and thirdly it can be used essentially without damage to the environment. In 
addition to its positive global effect in comparison with other sources of energy, it presents no risk of major accidents, as do nuclear and oil energy. Due to their heterogeneous nature, biomass materials possess inherently low bulk densities, and thus it is difficult to efficiently handle large quantities of most feed stocks. Therefore, large expenses are incurred during material handling (transportation, storage, etc.).

Biomass is defined as bio residue available by water based vegetation, forest or organic waste, by product of crop production, agro or food industries waste. Various biomass resources are available in India in different form. They can be classified simply in the way they are available in nature as: grasses, woody plants, fruits, vegetables, manures and aquatic plants. Algae and Jatropha are also now used for manufacturing bio-diesel. Core distinct sources of biomass energy can be classified as residue of agricultural crop, energy plantation and municipal and industrial waste.

Briquetting technology is one of the densification process. Biomass densification, which is also known as briquetting of sawdust and other agro residues, has been practiced for many years in several countries. The potential of biomass briquetting in India (in terms of power generation) was estimated at 61,000 MW, while the estimated employment generation by the industry is about 15.52 million and the farmers earn about $\$ 6$ per ton of farm residues (Gangadhar et al.,2015). To improve the characteristics of agricultural residues for transportation, storage and energy generation, it may be necessary to upgrade the raw agricultural by increasing its bulk density by the densification process.

Recently dependence on fossil fuels started to hasten due new oil and gas discoveries and exploitations. In the very near future charcoal is expected to be replaced by natural gas in most of the big cities, but in most of the rural areas and the small towns the situation of dependence on forests may remain unchanged for more few years.

Biomass briquettes are a bio fuel substitute to coal and charcoal. Biomass briquettes are made from agricultural and forestry waste. The low density biomass(agricultural and forestry waste) is converted into high density biomass briquettes with the help of a briquetting machine that uses binder or binder less technique, without using any type of chemical so it is $100 \%$ natural. The major raw material for biomass briquette are, Mustard Stalks, Sawdust, Rice Husk, Coffee Husk, Coir Pitch, Jute Sticks, Sugarcane, Groundnut Shell, Cotton Stalks, Caster Seed Shells / Stalk, Wood Chips, Bamboo Dust, Tobacco Waste, Tea Waste, maize stalks, bajra cobs, Arhar stalks, Paddy Straw, Wheat Straw, Sunflower Stalk, Palm Husk, Soya bean Husk, Veneer Residues, Barks \& Straws, Leafs, Pine Niddle, Seeds Cases etc. Biomass Briquette are widely used for any type of thermal application like steam generation in boilers, in furnace \& foundries, for heating purpose (Residential \& Commercial Heating), drying process and in gasification.

With a view to improving the briquetting scene in India, the Indian Renewable Energy Development Agency (IREDA) - a finance granting agency - has financed many briquetting projects, all of which are using piston presses for briquetting purposes. Holding meetings with entrepreneurs at different levels, providing technical back-up shells and educating entrepreneurs have to some extent helped some plants to achieve profitability and holds out hope of reviving the briquetting sector. India is the only country where the briquetting sector is growing gradually in spite of some failures. As a result of a few successes and IREDA's promotional efforts, a number of entrepreneurs are 
confidently investing in biomass briquetting. These entrepreneurs are also making strenuous efforts to improve both the production process and the technology.

Historically, biomass briquetting technology has been developed in two distinct directions. Europe and the United States has pursued and perfected the reciprocating ram/piston press while Japan has independently invented and developed the screw press technology.

Although both technologies have their merits and demerits, it is universally accepted that the screw pressed briquettes are far superior to the ram pressed solid briquettes in terms of their storability and combustibility.

At present the main type of technologies are used for briquetting:

\section{Piston Press}

\section{Screw extrusion press}

Hydraulic press and

\section{Roller press}

The piston press type briquetting machine is older than the screw type briquetting machine in India previously. While the briquettes produced by a piston press are completely solid, screw press briquettes on the other hand have a concentric hole which gives better combustion characteristics due to a larger specific area. The screw press briquettes are also homogeneous and do not disintegrate easily.

\section{Working Principle of Briquetting Machine}

Initially the mixture of biomass (sawdust/cowdung mixture and rice husk/cowdung mixture) is poured into the compaction cylinders. In this concept a person rotates the arm handle which force the screw shaft to move downward. Due to this downward movement of screw, the top plate attached with the piston cylinder also move downward. Thereafter the piston squeezes the biomass mixture into the cylindrical compression chamber. Due to this compaction the biomass deforms and interlock, in which cowdug is used as binder. The compressed biomass was densify and take the shape of the cylindrical die. This final compacted and densify solid body is called Briquette.

\section{Design Consideration}

The design consideration was based on the forces required to drive the shaft, materials fed, load bearing capacity when power is transmitted by the screw shaft, power required to compact pulverized feedstock as well as texture of the excluded resultant briquette from the die.

\section{Selection of Materials}

The materials used for making briquetting machine are wrought iron, cast iron and G.I. (galvanised iron). The details of materials used along with their specifications are given below:-

\section{Wrought Iron}

Wrought iron is the purest form of iron. It is an iron alloy with very low carbon content with respect to cast iron. It is ferrous material and more corrosion resistance than steel. Its Specifications are:-

It is soft, ductile, magnetic and has high elasticity and tensile strength.

It can be heated and reheated and worked into various shapes. 
It is used for pipe making due to its superior corrosion and fatigue resistance and better welding and threading qualities.

\section{Cast Iron}

Cast iron is a ferrous alloy that is made by remelting pig iron in a cupola furnance until it liquefies. It is strong structural material and good conductor of heat. The four basic types of cast iron- white iron, gray iron, ductile iron, malleable iron. Its specifications are:-

It has long lasting durability, cast iron isn't going to crack or dent

The excellent machinability of cast iron helps in cutting it and getting the finish within less time.

The durable nature helps to prevent defomation.

\section{Galvanised Iron}

In galvanization, the iron is applying with a protective zinc coating to prevent rusting. The most common method is hot-dip galvanizing, in which the parts are submerged in a bath of molten zinc. Its specifications are:-

Higher durability and longevity.

Weld consistency and integrity.

Superior finish and anti-rust coating.

Great resistance to corrosion

\section{Components of Machine}

Frame

Screw shaft

Compaction chamber
Piston type compressor

Perforated base plate

Bearing

Handle

Stand

\section{Frame}

The main frame supports the other parts of the machine. The main body of the machine was made by using the iron angle and iron bar. Main frame was welded to the compaction cylinder through an iron angle. The sliding plate was fitted into the iron bar, for the sliding movement of the piston.

\section{Screw shaft}

Screw shaft is a rotating element of the machine, its upper part is connected to the handle through a bolt and lower part is connected to the piston plate, which is used to lift or lower the piston plate by transmitting the power.

\section{Compaction chamber}

In Compaction chamber, the pulvarised feedstock is compacted through the piston. Pressure was generated in the compaction chamber through the piston, for the removal of excess water. It should be used as a mould to the pulverized feedstock. The cylinder were made such that, there was a clearance of about 1 inch between the piston head and perforated plate to allow the escape of water during compaction

\section{Piston type compressor}

Four pressure transmitting piston cylinders were welded to the plate. These pistons went into the holes of the compaction chamber, 
which is pressurized by the piston plate through the screw shaft.

\section{Perforated base plate}

For the removal of excess water from the mixture, perforated base plate is used. When mixture was compacted into the compaction chamber, the excess moisture removes through the base plate. It is tightened through a screw and loosens when needed.

\section{Bearing}

A bearing is a component, used between the two parts that allow the rotational movement.
For the smooth operation of shaft, bearing mechanism should be used.

\section{Handle}

Handle is given for the smooth rotation of the screw shaft.

\section{Stand}

The stand is given for the support of the machine. It gives a certain height to the machine so that the briquettes could properly remove from the bottom. It is a integrated part which was not welded to the main frame.

Table.1 Specification of developed manually operated briquetting machine

\begin{tabular}{|c|c|c|c|c|}
\hline S.No & Component & $\begin{array}{c}\text { Physical } \\
\text { Parameters }\end{array}$ & Materials Used & Dimension \\
\hline \multirow{3}{*}{1} & \multirow{3}{*}{ Frame } & Length $(\mathrm{cm})$ & \multirow{3}{*}{ Angle iron } & $10 \mathrm{~cm}$ \\
\hline & & Width $(\mathrm{cm})$ & & $10 \mathrm{~cm}$ \\
\hline & & Height $(\mathrm{cm})$ & & $47 \mathrm{~cm}$ \\
\hline \multirow[t]{2}{*}{2} & \multirow[t]{2}{*}{ Piston } & Diameter $(\mathrm{cm})$ & \multirow[t]{2}{*}{ Iron } & $7.7 \mathrm{~cm}$ \\
\hline & & Height $(\mathrm{cm})$ & & $13.7 \mathrm{~cm}$ \\
\hline \multirow[t]{2}{*}{3} & \multirow[t]{2}{*}{ Piston plate } & Length $(\mathrm{cm})$ & \multirow[t]{2}{*}{ Iron } & $10 \mathrm{~cm}$ \\
\hline & & Width $(\mathrm{cm})$ & & $10 \mathrm{~cm}$ \\
\hline \multirow[t]{2}{*}{4} & \multirow{2}{*}{ Compaction cylinder } & Diameter $(\mathrm{cm})$ & \multirow{2}{*}{ Galvanised Iron } & $11 \mathrm{~cm}$ \\
\hline & & Height $(\mathrm{cm})$ & & $15.3 \mathrm{~cm}$ \\
\hline \multirow[t]{2}{*}{5} & \multirow{2}{*}{ Perforated base plate } & Length $(\mathrm{cm})$ & \multirow{2}{*}{ Iron plate } & $10 \mathrm{~cm}$ \\
\hline & & Width $(\mathrm{cm})$ & & $10 \mathrm{~cm}$ \\
\hline \multirow[t]{2}{*}{6} & \multirow[t]{2}{*}{ Handle } & Diameter $(\mathrm{cm})$ & \multirow[t]{2}{*}{ Iron } & $2.2 \mathrm{~cm}$ \\
\hline & & Height $(\mathrm{cm})$ & & $13.2 \mathrm{~cm}$ \\
\hline \multirow[t]{2}{*}{7} & \multirow[t]{2}{*}{ Screw shaft } & Diameter $(\mathrm{cm})$ & \multirow[t]{2}{*}{ Wrought iron } & $2.5 \mathrm{~cm}$ \\
\hline & & Height $(\mathrm{cm})$ & & $32.4 \mathrm{~cm}$ \\
\hline 8 & Bearing & & Cast Iron & P208 \\
\hline \multirow[t]{3}{*}{9} & \multirow[t]{3}{*}{ Stand } & Length $(\mathrm{cm})$ & \multirow[t]{3}{*}{ Iron } & $26.9 \mathrm{~cm}$ \\
\hline & & Width (cm) & & $31.8 \mathrm{~cm}$ \\
\hline & & Height $(\mathrm{cm})$ & & $30.7 \mathrm{~cm}$ \\
\hline
\end{tabular}


Fig.1 Components of Briquetting machine

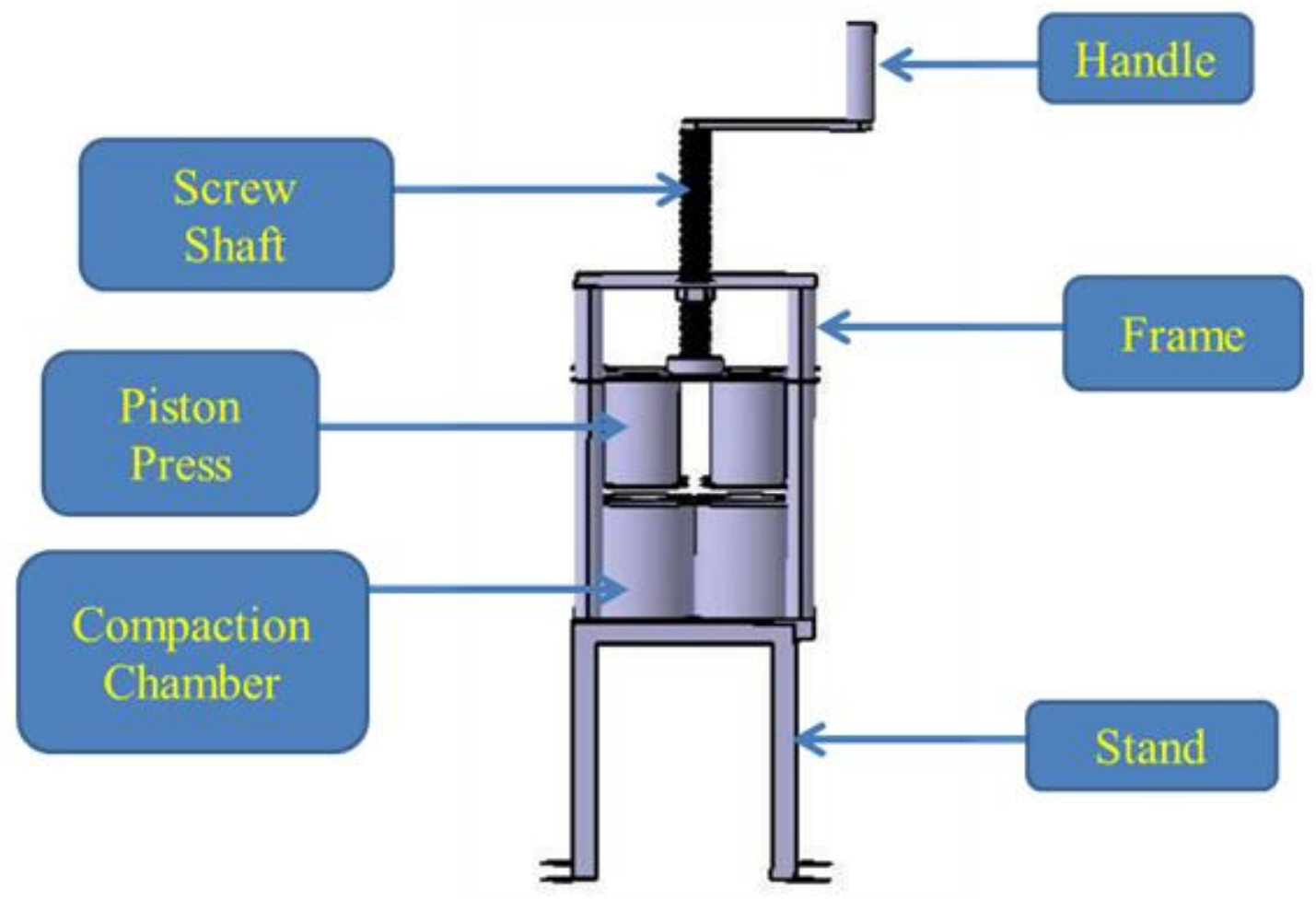

Development of manually operated briquetting machine

The manually operated briquetting machine has been developed of overall dimension $75 \times 24 \times 24 \mathrm{~cm}$. This machine consist of a screw shaft of height $32 \mathrm{~cm}$ as a rotating element which transmit power to the piston.

The specification of manually operated briquetting machine is shown in Table. Developed manually operated briquetting machine is shown in fig

A screw press briquette machine has been developed and fabricated. This machine has the capacity to produce four briquettes at a time.

It was fabricated with materials sourced locally, hence its maintenance and sustainability is assured. The cost of the Briquetting machine was approximately Rs.4200. Good progress of the work has been made successfully.

\section{References}

Allan Yambot, Leo Casano, Ryan Mina, Kevin Yu, and Alvin Chua (2016).Automated Screw Type Briquetting Machine as A Small Business Venture.International Journal of Automation and Smart Technology.6(04):185-189.

Aries Roda D. Romallosa (2017). Quality Analyses of Biomass Briquettes Produced using a Jack-Driven Briquetting Machine.Journal of Applied Science and Technology.7(1)8-16. 
Arinola, B. Ajayi, JustinaOsumune, I. (2013). Design of Sawdust Briquette Machine.Innovative Systems Design and Engineering. www.iiste.org. 4(10):51-58.

Bhattacharya, S.C., M. Augustus Leon and Md. MizanurRahman.A Study on Improved Biomass Briquetting.Energy Program, School of Environment, Resources and Development Asian Institute of Technology P.O.Box 4, KlongLuang, Pathumthani 12120, Thailand.

Deepali S. Mandwe (2010). Design and development od briquetting machine for Eco-Friendly fuel. Thesis of Doctor of philosophy in agricultural engineering department of renewable energy sources college of technology and engineering.

Dongardive, S.N., Wankhade, A.M., More, D.D. and Rajankar D.D. (2018). Design and construction of low cast hand opreted briquetting machine. International Journal of Agriculture Sciences. 10(11):-6295-6297.

Grover P.D. \& Mishra S.K. (1996). Biomass briquetting: Technology and Practices.This publication is printed by the FAO Regional Wood Energy Development Programme in Asia, Bangkok, Thailand.

Gupta Anupriya (2018). Production of briquettes from sugarcane bagassecow dung mixture and its characterization.M. Tech. (Agril. Engg.) Thesis of Maharana pratap university of agriculture and technology, Udaipur.

IlochiNkechinyere Olivia and Oti Wilberforce J.O. (2017). The design and fabrication of a briquette press using locally available raw material in Nigeria. Indo American Journal Of Pharmaceutical Sciences.4(02):450-456.

Manjunatha (2017).Design and development of shredder cum briquetting machine. College Of Agricultural Engineering And Technology Vasantro Naik Marathwada Krishi Vidyapeeth Parbhani- 431402 (M. S.) India.

NenavathManikyam (2018). Design and development of deep placement urea briquette applicator attachment for self propelled rice transplanter.Indira Gandhi KrishiVishwavidyalaya Raipur (Chhattisgarh).

Ojaomo, E.K., Maliki, O.B. and Olusanya, A.J. (2015).Development of a Simple Briquetting machine for Small Scale Application. International Journal of Engineering Research \& Technology. 4 (05):1428-1432.

Oladeji, J.T. (2010). Fuel Characterization of Briquettes Produced from Corncob and Rice Husk Resides.The pacific journal of science and technology.11(01):101106.

Oladeji, J.T.(2012). Comparative Study of Briquetting of Few Selected AgroResidues Commonly Found in Nigeria. The Pacific Journal of Science and Technology13(02):80-86.

Oladeji, J.T., (2010). Fuel Characterization of Briquettes Produced from Corncob and Rice Husk Resides. Department of Mechanical Engineering, Ladoke Akintola University of Technology, Ogbomoso, PMB 4000, Ogbomoso, Nigeria. 11(1):101-106.

Orhevba, B.A., Musa Umaru., Isah Abubakar Garba., Bilyaminu Suleiman, Mohammed Umar Garba, Nwatu Ernest (2016).Synthesis of Composite Biomass Briquettes as Alternative Household Fuel for Domestic Application.Proceedings of the World Congress on Engineering and Computer Science 2016 Vol II WCECS 2016, October 19-21, 2016, San Francisco, USA.

Osarenmwinda, J O; Ihenyen O.I (2012).The 
Preliminary Design and Fabrication of a Manually Operated Briquetting Machine.J. Appl. Sci. Environ. Manage. June. 16 (2):209 - 211.

Osarenmwinda, Jo; Ihenyen O.I. (2012)The Preliminary Design and Fabrication of a Manually Operated Briquetting Machine. Deprimert of Production Engineering, University of Benin, Benin City, Nigeria.J. Appl. Sci. Environ. Manage. 16(2):209 - 211.
Prajapati,A.k. (2006). Development of briquettes from jatropha (ratanjot) oil cake.Maitabana Pratap University of agriculture and technology Udaipur.

Sahu, Parmanand, Victor, V.M., Jogdand, S.V. and Yadaw Madhuri (2015). Development of Animal Power Briquetting Machine to Produce Low Density Briquettes. International Journal of Engineering Research \& Technology 4(07):1192-1198.

\section{How to cite this article:}

Yomesh Sinha, Pujyalal Sahu, Swarup Biswas, Shivangi Manikpuri and Manish Lathiya. 2019. Development of Manually Operated Piston Press Typebriquetting Machine. Int.J.Curr.Microbiol.App.Sci. 8(12): 2932-2939. doi: https://doi.org/10.20546/ijcmas.2019.812.340 